\title{
PHOTOGRAMMETRY-DERIVED ORTHOIMAGERY AND ELEVATION FOR BARRY ARM LANDSLIDE, SOUTHCENTRAL ALASKA, JUNE 27, 2020
}

Katreen Wikstrom Jones, Gabriel J. Wolken, Ronald P. Daanen, and Andrew M. Herbst

Raw Data File 2021-5

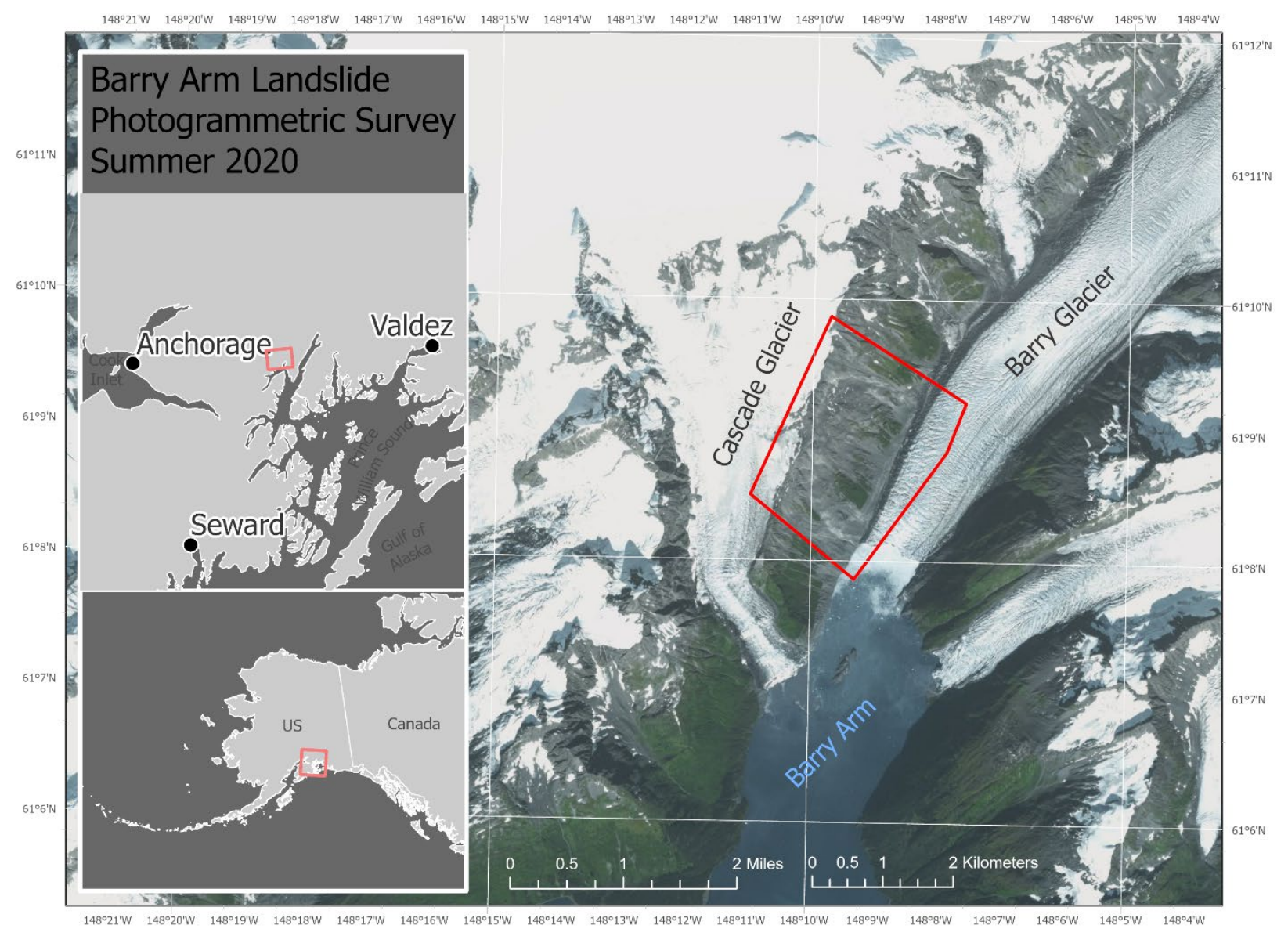

Location map of survey area with orthoimagery.

This report has not been reviewed for technical content or for conformity to the editorial standards of DGGS.

2021

STATE OF ALASKA

DEPARTMENT OF NATURAL RESOURCES

DIVISION OF GEOLOGICAL \& GEOPHYSICAL SURVEYS

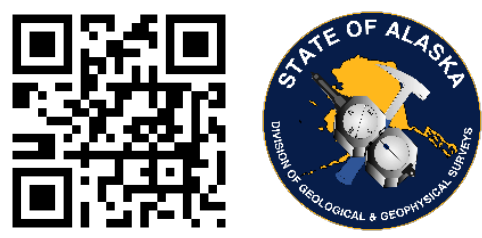


STATE OF ALASKA

Mike Dunleavy, Governor

DEPARTMENT OF NATURAL RESOURCES

Corri A. Feige, Commissioner

\section{DIVISION OF GEOLOGICAL \& GEOPHYSICAL SURVEYS}

Steve Masterman, State Geologist \& Director

Publications produced by the Division of Geological \& Geophysical Surveys are available to download from the DGGS website (dggs.alaska.gov). Publications on hard-copy or digital media can be examined or purchased in the Fairbanks office:

\section{Alaska Division of Geological \& Geophysical Surveys (DGGS)}

3354 College Road | Fairbanks, Alaska 99709-3707

Phone: 907.451.5010 | Fax 907.451.5050

dggspubs@alaska.gov | dggs.alaska.gov

DGGS publications are also available at:

Alaska State Library, Historical

Collections \& Talking Book Center

395 Whittier Street

Juneau, Alaska 99801

Alaska Resource Library and

Information Services (ARLIS)

3150 C Street, Suite 100

Anchorage, Alaska 99503

\section{Suggested citation:}

Wikstrom Jones, Katreen, Wolken, G.J., Daanen, R.P., and Herbst, A.M., 2021, Photogrammetry-derived orthoimagery and elevation data for Barry Arm landslide, Southcentral Alaska, June 27, 2020:

Alaska Division of Geological \& Geophysical Surveys Raw Data File 2021-5, 6 p. http://doi.org/10.14509/30596

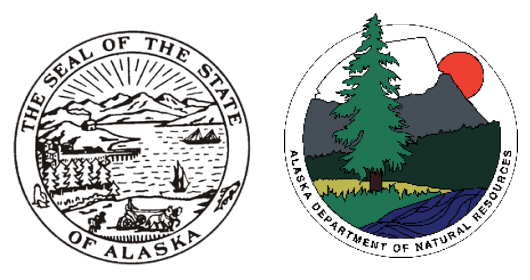




\title{
PHOTOGRAMMETRY-DERIVED ORTHOIMAGERY AND ELEVATION DATA FOR BARRY ARM LANDSLIDE, SOUTHCENTRAL ALASKA, JUNE 27, 2020
}

\author{
Katreen Wikstrom Jones ', Gabriel J. Wolken', Ronald P. Daanen', and Andrew M. \\ Herbst $^{1}$
}

\section{INTRODUCTION}

The State of Alaska Division of Geological \& Geophysical Surveys (DGGS) used Structurefrom-Motion (SfM) photogrammetry from an unmanned aerial system (UAS) to produce a digital surface model (DSM) and orthoimagery of a large landslide in northern Barry Arm, northwest Prince William Sound, Alaska, during near snow-free ground conditions on June 27, 2020. The goal of the survey is to provide snow-free surface elevations and imagery data for the purpose of assessing landslide movement with repeat surveys during snow-free surface conditions. This data release is one of a series of DGGS publications to present elevation data. The photogrammetry and Global Navigation Satellite System (GNSS) data were collected on June 26-27, 2020, and processed using Agisoft Metashape. This data collection is being released as a Raw Data File with an open end-user license. All files can be downloaded free of charge from the DGGS website at https://doi.org/10.14509/30596.

\section{LIST OF DELIVERABLES}

Hydro-enforced DSM

Orthoimagery

Metadata

\section{MISSION PLAN}

\section{Aerial Photogrammetric Survey Details}

DGGS used a WingtraOne unmanned aircraft system (UAS) platform with a Sony RX1R2 camera with an DSC-RX1RM2 $(35 \mathrm{~mm})$ lens to collect 42.4-megapixel JPEG photographs (7952 x 5304 pixels per image). The aerial photographic survey was controlled with an onboard intervalometer that linked the camera shutter release with Global Navigation Satellite System (GNSS) event markers.

The aerial photogrammetric survey resulted in 70 percent side lap and 70 percent end lap coverage, and 1624 photos with $0.046 \mathrm{~m}$ per pixel ground resolution. This survey was flown with an average elevation of $224 \mathrm{~m}$ above ground level and a ground speed of approximately $16 \mathrm{~m} / \mathrm{s}$. The total area surveyed was approximately $6 \mathrm{~km}^{2}$.

\footnotetext{
${ }^{1}$ Alaska Division of Geological \& Geophysical Surveys, 3354 College Road, Fairbanks, Alaska 99709
} 


\section{Weather Conditions and Flight Times}

The survey was flown on June 27, 2020. Flight take-off occurred at 12:01 pm from the ridge near the base station and landing occurred at approximately 2:30 pm at the same location (figure 1). During the survey, the operator returned the UAS three times to the take-off location in order to change batteries. The weather throughout the survey was fair and sky was clear. No abnormalities were observed during the flights.

\section{PROCESSING REPORT}

\section{Photogrammetric Dataset Processing}

Aerial survey Global Navigation Satellite System (GNSS) data (camera coordinates and trajectory data) were processed by DGGS using kinematic (PPK) methods in WingtraHub. Camera coordinates were automatically registered to image filenames to create a camera exterior orientation file for import into the photogrammetric software, Agisoft Metashape Professional. The exterior orientation file provides the $\mathrm{X}, \mathrm{Y}$, and $\mathrm{Z}$ position for each photograph taken during the survey. Yaw, pitch, and roll information were not recorded during the flight.

Aerial stereo-photographs were imported into the commercially available Agisoft Metashape Professional software (Version 1.6.3 build 10732). Photos were processed in Metashape on a Windows PC to align aerial photos, georeference aerial photos using ground control points placed on photo-identifiable markers, edit the sparse point cloud, optimize the bundle block adjustment, construct the dense point cloud and triangulated irregular network geometry, and export the mosaiced natural color (RGB) orthoimagery and digital surface model GeoTIFFs.

\section{Orthoimagery}

The orthoimagery is a four-band, 8-bit unsigned GeoTIFF file. The orthoimagery has a ground sample distance (GSD) of $0.046 \mathrm{~m}$ per pixel, and the "No Data" value is set to 256.

\section{Hydro-Enforced Digital Surface Model}

The hydro-enforced digital surface model (DSM) represents surface elevations-for example, heights of vegetation, buildings, bridges, etc.-which have undergone a selective "flattening" process, where elevation values for any hydrologic features, as well as any hydrologic obstacles (bridges, culverts, etc.), are replaced with neighboring pixel values. The hydro-enforced DSM is a single-band, 32-bit float GeoTIFF file, with a ground sample distance of 0.093 meters. The "No Data" value is set to $-3.40282306074 \mathrm{e}+038$

\section{SURVEY REPORT}

\section{Ground Survey Details}

A Global Positioning System (GPS) base station with a Trimble R10-2 receiver sampling at $5 \mathrm{~Hz}$ was placed centrally in the upper portion of the survey area on June 26-27, 2020, to provide a base station and real-time kinematic (RTK) corrections to points surveyed with a rover Trimble R10-2 GNSS receiver (internal antenna). Four photo-identifiable markers were collected on June 26,2020 , prior to the photogrammetric survey for calibration and assessment of the horizontal and vertical accuracy of the point cloud. 


\section{Coordinate system and Datum}

All data were processed and delivered in NAD83 (2011) UTM6N and vertical datum NAVD88 GEOID12B.

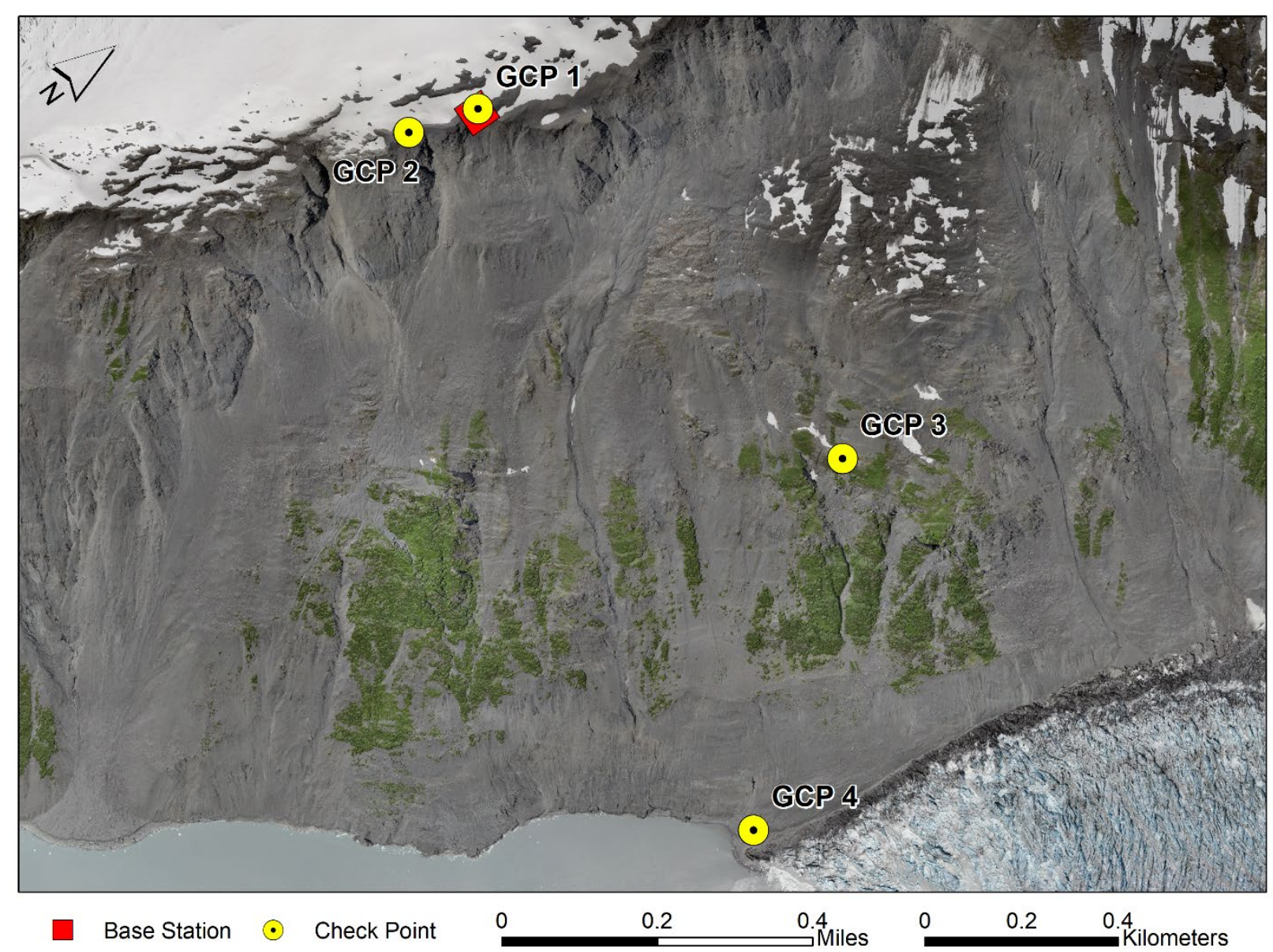

Figure 1. Location of photo-identifiable ground control points that were used to georeference the photos and to evaluate horizontal and vertical accuracy of the final products.

\section{Horizontal Accuracy}

The average camera location error was $0.0054 \mathrm{~m}$ in the $\mathrm{X}$ direction, $0.0052 \mathrm{~m}$ in the $\mathrm{Y}$ direction, and $0.0091 \mathrm{~m}$ in the $\mathrm{Z}$ direction, with a combined $\mathrm{XY}$ error of $0.0075 \mathrm{~m}$ and resulting total error of $0.0117 \mathrm{~m}$. Horizontal accuracy of the DSM and orthoimagery was assessed by comparing the locations of the same four photo-identifiable markers that were used in the data processing (figure 1). The mean offset (residual) was $0.2804 \mathrm{~m}$ in the $\mathrm{X}$-direction and $0.8554 \mathrm{~m}$ in the Y-direction, with a standard deviation of $0.05 \mathrm{~m}$ and $0.1827 \mathrm{~m}$, for $\mathrm{X}$ - and Y-directions respectfully, and a mean-absolute error (MAE) of $0.31 \mathrm{~m}$ (0.8554 m, Y-direction) (table 1). A horizontal transformation of $-0.2804 \mathrm{~m}$ in the $\mathrm{X}$-direction and $-0.8554 \mathrm{~m}$ in the $\mathrm{Y}$-direction were 
applied because horizontal offsets were above the pixel scale $(0.046 \mathrm{~m} \mathrm{GSD})$. The final error of the adjusted products have a mean offset (residual) in the X-direction of $0.0057 \mathrm{~m}$ (MAE of 0.04450 ) and in the Y-direction -0.0094 $\mathrm{m}$ (MAE of 0. $1261 \mathrm{~m}$ ).

\section{Vertical Accuracy}

Vertical accuracy of the DSM was assessed by comparing the elevation values of 22,693 points in the XY-shifted DSM against a lidar-derived digital terrain model (acquired on June 26, 2020) in Quick Terrain Modeler software. A mean offset of $2.1682 \mathrm{~m}$ was measured between the two DSMs. This offset was reduced to -0.2591 by performing a vertical transformation of the photogrammetry-derived DSM. The four photo-identifiable ground control points were used as check points to determine the non-vegetated vertical accuracy (NVA) of the DSM (figure 1). DSM NVA was calculated to have a mean absolute error (MAE) of $0.1611 \mathrm{~m}$ after vertical transformation (app. 1).

\section{Data Consistency and Completeness}

The DSM and orthoimagery have been visually inspected for data errors such as pits, border artifacts, and shifting. There are a few holes in the data over the fjord due to waves on the water. These holes appear in the orthoimage only; the water surface in the DSM has been hydroenforced.

\section{ACKNOWLEDGMENTS}

These data products were funded, collected, and processed by DGGS. We thank the University of Alaska Fairbanks, Alaska Climate Adaptation Science Center for supplying the WingtraOne UAS, and Alpine Air for their aviation expertise and contribution to these data products. 


\section{Appendix 1. Checkpoints}

\begin{tabular}{|c|c|c|c|c|c|c|}
\hline $\begin{array}{l}\text { Check } \\
\text { Point }\end{array}$ & Easting (X) & Northing $(Y)$ & Elevation (m) & $\begin{array}{l}\text { Horizontal } \\
\text { Offset } X(m)\end{array}$ & $\begin{array}{l}\text { Horizontal } \\
\text { Offset } Y(m)\end{array}$ & $\begin{array}{c}\text { Vertical } \\
\text { Offset } Z(m)\end{array}$ \\
\hline 1 & 437047.7980 & 6779843.5690 & 1096.6510 & 0.0773 & 0.0143 & -0.0010 \\
\hline 2 & 437006.0420 & 6779698.9200 & 1081.2610 & 0.0409 & -0.0456 & -0.0010 \\
\hline 3 & 438072.7270 & 6780047.0310 & 535.5770 & 0.1152 & -0.0321 & 0.0620 \\
\hline \multirow[t]{5}{*}{4} & 438596.5910 & 6779456.5130 & 4.4570 & -0.2709 & 0.0862 & -0.5802 \\
\hline & & & Mean & -0.0094 & 0.0057 & -0.2591 \\
\hline & & & $\begin{array}{l}\text { Standard } \\
\text { Deviation }\end{array}$ & 0.1770 & 0.0595 & 0.3016 \\
\hline & & & Range & 0.3861 & 0.1318 & 0.6422 \\
\hline & & & $\begin{array}{l}\text { Mean } \\
\text { Absolute } \\
\text { Error }\end{array}$ & 0.1261 & 0.0445 & 0.1611 \\
\hline
\end{tabular}

